\title{
ASSESSMENT OF GROUNDWATER QUALITY AND ASSOCIATED HEALTH RISKS IN RURAL AREAS OF SINDH (PAKISTAN)
}

\author{
MUHAMMAD SARFRAZ ${ }^{\mathrm{a},{ }^{*},}$, NARGIS SULTANA ${ }^{\mathrm{b}}$, \\ MUHAMMAD ILYAS TARIQ ${ }^{\mathrm{b}}$
}

\begin{abstract}
Groundwater quality has considerable impact on public health, especially in areas where majority of the people rely on groundwater for drinking purpose. In this scenario, investigation of 175 groundwater samples collected from district Jacobabad and Kashmor, Sindh Pakistan was carried out for physicochemical parameters (color, odor, taste, $\mathrm{pH}$, EC, turbidity, alkalinity hardness, $\mathrm{Cl}, \mathrm{SO}_{4}^{-2}, \mathrm{NO}_{3}^{-}$and TDS), major cations $\left(\mathrm{Na}^{+}, \mathrm{K}^{+}, \mathrm{Ca}^{+2}\right.$ and $\left.\mathrm{Mg}^{+2}\right)$, trace elements ( $\mathrm{F}, \mathrm{As}$, Fe and $\mathrm{Zn}$ ) and microbiological organisms (total coliform and faecal coliform). Analysis results showed high level of microbial contamination as 66 and $62 \%$ sampling sites were laden with total coliform and faecal coliform organisms respectively. On the other hand, chemicals constituents like hardness, $\mathrm{Ca}, \mathrm{Mg}, \mathrm{Na}, \mathrm{K}, \mathrm{SO}_{4}, \mathrm{Cl}$, and TDS in 54, $72,21,47,25,73$ and $49 \%$ water samples respectively were higher than GVs. Other than this, trace elements like $\mathrm{F}, \mathrm{Zn}, \mathrm{As}$ and $\mathrm{Fe}$ were also found in high concentration in 11, 04, 22 and 53\% water samples respectively. Health risk assessment due to $\mathrm{Fe}$, As and $\mathrm{Zn}$ revealed that arsenic $\mathrm{HRI}>1$ in 22 and 13\% water samples for children and adults respectively and overall CDIs and HRI were found in the order of $\mathrm{As}>\mathrm{Zn}>\mathrm{Fe}$ whereas, pollution index (Pi) for Fe was significant among all trace elements investigated.
\end{abstract}

Keywords: Contamination; pollution index; risk assessment; trace metals; groundwater.

\section{INTRODUCTION}

Quality of groundwater, the major source of drinking water and household use [1] is deteriorated by a number of things including materials on seepage routes, general human activities, sewerage or disposal system

\footnotetext{
a Pakistan Council of Research in Water Resources (PCRWR), MoST, Pakistan.

* Corresponding author e-mail: sarfrazzed@gmail.com

b Department of Chemistry, University of Sargodha, 40100, Pakistan.
} 
and dissolved solids and minerals. Flooding, one of the major natural disasters causes contamination of water by mixing different kinds of contaminants like industrial, human and animal wastes into the water body through unprotected bore holes and surface water sources. Waterborne diseases are the major threat to the healthy lives of the people. Literature shows that waterborne disease as a result of faecal pollution of drinking water wiped out entire population of cities [2]. It is estimated that nearly $80 \%$ of total diseases like diarrhea, dysentery, hepatitis, tooth decay and anemia in children are due to consumption of poor quality water [3]. In Pakistan over $40 \%$ of urban deaths are linked to waterborne diseases originated due to consumption of contaminated water [4]. A number of studies have been documented on severe contamination of drinking water sources with hazardous pathogenic bacteria like Shigella sp., V. cholerae, $P$. aeruginosa, Salmonella, and $S$. aureus in different areas of Pakistan caused by recent floods, which have resulted diseases like diarrhea, cholera, typhoid fever, food poisoning, dysentery, gastroenteritis, and other serious infections [5-8].

Minerals and micronutrients are considered to be an essential part of drinking water but their excess beyond certain limit causes serious health implications. Calcium is considered to be an important component of basic structure of bone, soft tissues and teeth but its excess intake can interact with iron, magnesium, zinc, and phosphorus within the intestine and reduces their absorption. Higher concentrations of sulphate along with sodium and magnesium impair water taste and have laxative effect. Similarly, high concentration of sodium aid in increasing consumer's blood pressure. It has been reported that all hand pumps and $73 \%$ well water are not potable due to excess of nitrate, magnesium and sulphate in district Bannu (KPK), Pakistan [9].

Trace elements like fluoride, iron, zinc and arsenic can cause complex health hazards if ingested in excess for prolonged time, therefore, it is necessary to estimate potential health risk associated with these elements. Different studies conducted to evaluate heavy metal concentration and health risk assessment showed that overall all of these metals in excess concentration are toxic [4], [10]. Due to ingestion of As rich water, it is estimated that about 200 million people globally are at the health risk of As poisoning [11]. A number of other investigations have also been carried out to evaluate physicochemical and microbiological quality of drinking water and possible health risks [8], [12-15]. Similarly, high concentration of different minerals and trace metals have also been highlighted in a recent study conducted in district, Rajanpur, Pakistan [16]. Physicochemical and microbiological investigation of drinking water quality and possible health risks assessment have been carried out through a number of other studies 
which revealed that most of water samples have chemical and/or microbiological contamination and are unsuitable for human consumption as found in Pakistan [13-14], [17], Cambodia [18], Ghana [19], Bangladesh [20], Romania [21], and many other Asian and European countries along with USA $[22,23]$.

In order to explore post flood groundwater profile, we have designed present research study to evaluate physicochemical and microbiological status and health risk associated with consumption of available potable groundwater in flood affected rural areas of district Jacobabad and Kashmor, Sindh, Pakistan.

\section{RESULT AND DISCUSSION}

Water samples collected under present investigated were evaluated for physico-chemical parameters (color, odor, $\mathrm{pH}$, turbidity, conductivity, alkalinity, $\mathrm{Cl}^{-}, \mathrm{SO}_{4}{ }^{-2}, \mathrm{NO}_{3}^{-}$and TDS), major cations $\left(\mathrm{Na}^{+}, \mathrm{K}^{+}, \mathrm{Ca}^{+2}, \mathrm{Mg}^{+2}\right)$, trace elements ( $\mathrm{Fe}, \mathrm{F}, \mathrm{As}$ and $\mathrm{Zn}$ ) and microbiological constituents (total coliform and faecal coliform) and finally analysis results were compared with guidelines values (GVs). Range and mean values of major water quality indicators are shown in Table 1 whereas detail regarding sampling locations and variation of major water quality parameters as supplementary information can be available from the authors upon request.

\section{Physico-chemical parameters}

Evaluation of physical and aesthetic indicators like taste, odour, colour and turbidity showed that most of the water samples were in agreement with GVs with the exception of a few having saline taste. Analysis data indicated that $\mathrm{pH}$ ranged from 6.60-8.26 which was in accordance with WHO GVs of 6.5-8.5 [2]. Conductivity is an indicator of ions concentration and their mobility, therefore, an increase in ion concentration increases EC of water [18]. In present investigation EC varied from $550 \mu \mathrm{S} / \mathrm{cm}$ to $28040 \mu \mathrm{S} / \mathrm{cm}$ which indicates high level of dissolved ionic concentration. Generally, conductivity of water samples collected from district Jacobabad was higher than Kashmor and highest value of $28040 \mu \mathrm{S} / \mathrm{cm}$ was recorded for sample collected from village Rehmatullah Khoso. Alkalinity is also an important constituent of water but its concentration beyond certain limit is associated with problems like hardness, gas trouble, kidney stone, severe irritation of eyes, skin, and mucous membrane and damage of metallic pipes [24]. Analysis data showed that in presented study alkalinity ranged from $120-513 \mathrm{mg} / \mathrm{L}$. 
Table 1: Range and mean value of physico-chemical parameters

\begin{tabular}{cccccc}
\hline Parameter & Range & Mean & Parameter & Range & Mean \\
\hline $\mathrm{EC}(\mu \mathrm{S} / \mathrm{cm})$ & $550-28040$ & 3953 & $\mathrm{Na}(\mathrm{mg} / \mathrm{L})$ & $34-2900$ & 456 \\
$\mathrm{pH}$ & $6.60-8.26$ & 7.4 & $\mathrm{~K}(\mathrm{mg} / \mathrm{L})$ & $2-130$ & 12.2 \\
Turbidity $(\mathrm{NTU})$ & $0.4-8.9$ & 1.7 & $\mathrm{Ca}(\mathrm{mg} / \mathrm{L})$ & $20-1280$ & 218 \\
Hardness $(\mathrm{mg} / \mathrm{L})$ & $110-8550$ & 1047 & $\mathrm{Mg}(\mathrm{mg} / \mathrm{L})$ & $9.7-1446$ & 122 \\
Alkalinity $(\mathrm{mg} / \mathrm{L})$ & $120-513$ & 257 & $\mathrm{~F}(\mathrm{mg} / \mathrm{L})$ & $0.40-1.80$ & 1.05 \\
$\mathrm{SO}_{4}(\mathrm{mg} / \mathrm{L})$ & $32-3680$ & 745 & $\mathrm{Fe}(\mathrm{mg} / \mathrm{L})$ & $0.05-2.0$ & 0.42 \\
$\mathrm{NO}_{3}(\mathrm{mg} / \mathrm{L})$ & $0.01-12.6$ & 1.38 & $\mathrm{Zn}(\mathrm{mg} / \mathrm{L})$ & $0.50-4.50$ & 1.06 \\
$\mathrm{TDS}(\mathrm{mg} / \mathrm{L})$ & $315-14876$ & 2414 & $\mathrm{As}(\mu \mathrm{L} / \mathrm{L})$ & $0.0-15.35$ & 5.05 \\
\hline
\end{tabular}

Literature showed that elevated concentration of chloride may create problems in throat and digestive system along with imparting saline taste and corrosion problems [25]. Presented data showed that $\mathrm{Cl}$ ranged from $23-8575 \mathrm{mg} / \mathrm{l}$ and overall $49 \%$ water samples have high concentration of $\mathrm{Cl}$ than GVs. Higher $\mathrm{Cl}$ content was reported in water samples collected from villages Allah Dito, Lal Bux and Rehmatullah Khoso. The major portion of total hardness is caused by calcium and magnesium ions and its high level may instigate heart diseases in residents [26]. Hardness varied from $110-8550 \mathrm{mg} / \mathrm{l}$ and $54 \%$ water samples have higher level than WHO GVs. Similarly, it has been reported that people ingesting high SO4 through drinking water may face diarrhea [27]. In present study $\mathrm{SO}_{4}$ ranged from $32-3680 \mathrm{mg} / \mathrm{l}$ and overall $73 \%$ water samples possessed high SO4 contents than WHO GVs. Seawater intrusion is considered to be responsible for pollution of groundwater systems with high $\mathrm{Cl}$ and hardness in Shah Bundar area [28]. Water samples collected from the house of Sohbat Khan, village Rehmatullah Khoso and Ramzan, Village Jabar and Rasoolabad has highest value of hardness and $\mathrm{SO}_{4}$ respectively. Nitrate for only 02 water samples in presented data have high content than GVs. Literature shows that groundwater in Pakistan have very less concentration of nitrate, however, higher level may be reported due to different agriculture and non-agriculture sources [19]. High TDS is associated with taste, hardness, corrosion properties and tendency to incrustation. Presence of high concentration of $\mathrm{Na}, \mathrm{K}, \mathrm{Ca}, \mathrm{Cl}, \mathrm{SO}_{4}$ and many more minerals contribute towards high level of TDS that may cause gastrointestinal exasperation [29]. In the presented study, TDS varied from 315 to 14877 $\mathrm{mg} / \mathrm{L}$ and total of $115(66 \%)$ water samples have TDS value higher than WHO permissible limit (Fig. 1). 


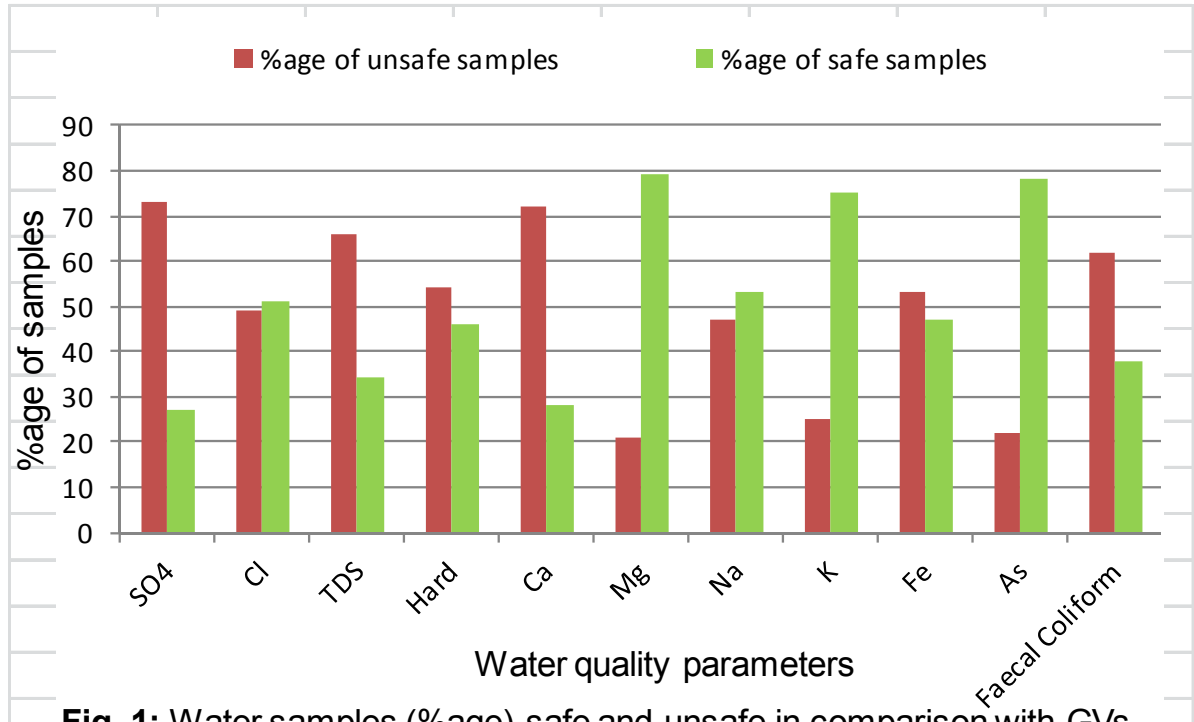

Fig. 1: Water samples (\%age) safe and unsafe in comparison with GVs

\section{Major cations}

Although, metals like $\mathrm{Na}, \mathrm{K}, \mathrm{Ca}$ and $\mathrm{Mg}$ are responsible for carrying out very important physiological functions in human body but an unsuitable intake and consumption of these minerals may lead towards health implications. Literature shows that short term exposure to high concentration of $\mathrm{Ca}$ does not create any health implications, but long time intake may lead towards hypercalcemia, urinary tract calculi and calcification in kidneys and in arterial walls besides suppression of bone re-modeling [7]. High level of $\mathrm{Na}$ is associated with an increase in blood pressure in children, male and female of all ages [30]. Potassium is an important micronutrient for living organisms but, excess amount in drinking water may lead towards nervous and digestive disorder [31]. It has been reported that hard water due to the association of $\mathrm{Mg}$ with $\mathrm{SO}_{4}$ ion may possess laxative properties and cause gastrointestinal disorders [15]. Presented data indicated that $72,21,47$ and $25 \%$ water samples have high concentration of $\mathrm{Ca}, \mathrm{Mg}, \mathrm{Na}$ and $\mathrm{K}$ respectively (Fig.1).

\section{Trace elements}

Present study indicated that $04,11,23$ and $53 \%$ water samples carry high content of Zn, F, As and Fe respectively (Fig. 1). Literature 
presents that tooth decay and skeletal and non-skeletal fluorosis is associated with higher concentration of $F$ in drinking water [32]. Intake of high contents of iron via food or drink may result toxic effects in human body. The formation of hydroxyl radicals and deposition of iron (due to these $\mathrm{Fe}^{+2}$ ions) in a typical kidney cell may harm kidney cells. The excess amount of iron may accelerate the formation of free radicals resulting in instigation of mutagenicity, nephrotoxicity and renal carcinoma [33]. Researcher documented that exposure to high level of As may cause hepatic, neurological, diabetic, hematological, cardiovascular, respiratory and reproductive effects in consumers. Carcinogenic symptoms including liver, skin, bladder, lung and kidney cancers are associated with exposure to high level of As [11]. In addition, consumption of arsenic contaminated water can also causes several noncancerous diseases such as liver disorders, hypertension, peripheral vascular diseases, diabetes mellitus and other respiratory and neurological issues [20].

\section{Health risk assessment}

Chronic daily intake (CDI) and health risk index (HRI) measurement for both children and adults were carried out to estimate health risk associated with ingestion of heavy metal as shown in Table 2. Calculated $\mathrm{CDI}$ values for $\mathrm{Fe}$, As and $\mathrm{Zn}$ ranged from 0.002-0.061, 0.0000.469 and $0.015-0.138 \mu \mathrm{g} \cdot \mathrm{kg}-1 \cdot \mathrm{day}-1$ and $0.001-0.056,0.000-0.426$ and $0.014-0.125 \mu \mathrm{g} \cdot \mathrm{kg}-1 \cdot \mathrm{day}-1$ for children and adults respectively. Calculated mean CDls were found in the order of $A s>Z n>F e$.

$\mathrm{HRI}$ assessment showed that As HRI value is higher than other metals and overall 22 and $13 \%$ water samples have HRI>1 for children and adults respectively indicating future consumer's health risk associated with consumption of polluted water for drinking purpose. HRI for $\mathrm{Fe}, \mathrm{As}$ and $\mathrm{Zn}$ ranged from 2.18E-06 to 8.74E-05, 0.000-1.565 and $5.10 \mathrm{E}-05$ to $4.59 \mathrm{E}-04$ for children and $1.98 \mathrm{E}-06$ to $7.94 \mathrm{E}-05,0.000$ 1.421 and $4.63 \mathrm{E}-05$ to $4.17 \mathrm{E}-04$ for adults respectively which indicate that $\mathrm{HRI}<1$ for $\mathrm{Fe}$ and $\mathrm{Zn}$. HRI calculations showed that heavy metals in ground water of district Rajanpur were found in order of $A s>Z n>F e$. Literature shows high to very high carcinogenic and non-carcinogenic health risk for both children and adults associated with elevated As concentration in drinking water and its correlation with $\mathrm{Fe}$ and other heavy metals [34]. 
ASSESSMENT OF GROUNDWATER QUALITY AND ASSOCIATED HEALTH RISKS ...

Table 2: Calculated range and mean values of $\mathrm{CDI}$ and $\mathrm{HRI}$ of trace metals

\begin{tabular}{|c|c|c|c|c|c|}
\hline & & \multicolumn{2}{|c|}{ CDI } & \multicolumn{2}{c|}{ HRI } \\
\hline \multirow{2}{*}{ Fe } & & Children & Adults & Children & Adults \\
\cline { 2 - 6 } & Range & $0.002-0.061$ & $0.001-0.056$ & $2.18 \mathrm{E}-06$ to $8.74 \mathrm{E}-05$ & $1.98 \mathrm{E}-06$ to $7.94 \mathrm{E}-05$ \\
\hline \multirow{2}{*}{ As } & Mean & 0.013 & 0.012 & $1.82 \mathrm{E}-05$ & $1.65 \mathrm{E}-05$ \\
\cline { 2 - 6 } & Range & $0.000-0.469$ & $0.000-0.426$ & $0.000-1.565$ & $0.000-1.421$ \\
\hline \multirow{2}{*}{ Zn } & Mean & 0.156 & 0.141 & 0.519 & 0.471 \\
\cline { 2 - 6 } & Range & $0.015-0.138$ & $0.014-0.125$ & $5.10 \mathrm{E}-05$ to $4.59 \mathrm{E}-04$ & $4.63 \mathrm{E}-05$ to $4.17 \mathrm{E}-04$ \\
\hline
\end{tabular}

\section{Pollution index (Pi)}

The $\mathrm{Pi}$ data showed that $\mathrm{Fe}$ have shown significant pollution amongst all the studied trace elements (Table 3).

Table 3: Pi data of trace elements in water samples

\begin{tabular}{|c|c|}
\hline Trace metals & Pollution index (Pi) \\
\hline $\mathrm{Fe}$ & 1.4 \\
\hline $\mathrm{Zn}$ & 0.4 \\
\hline $\mathrm{F}$ & 0.7 \\
\hline As & 0.5 \\
\hline
\end{tabular}

\section{Microbiological monitoring}

Present study revealed that 66 and $62 \%$ water samples are contaminated with total coliform and faecal coliform organism respectively as shown in Fig.1.Contamination of groundwater sources was evident from high level of open air defecation and practice of tethering animals close to human dwellings. Rain and flood water carry these human and animal's faecal wastes, which may carry pathogens and contaminates the water sources in the region and direct consumption from these sources may cause infectious diseases [28].

\section{CONCLUSION}

Physicochemical and microbiological assessment of groundwater being used for drinking purpose by residents of district Jacobabad and Kashmor revealed that there was high level of microbial contamination as $66 \%$ sites were found contaminated with total coliforms and another $62 \%$ 
were overloaded with faecal coliform bacteria. The study also highlighted that a large number of sampling sites were polluted with other chemicals, minerals and trace metals like $\mathrm{Ca}, \mathrm{SO}_{4}, \mathrm{Na}, \mathrm{K}, \mathrm{Fe}$, As and TDS. Health risk assessment showed that $\mathrm{HRI}>1$ for $A$ s in 22 and $13 \%$ water samples for children and adults respectively. Net result of present study is that most of the waterborne diseases prevailing in the region are due to consumption of substandard water after flood. A concrete policy should be devised to treat the ground water and address post-flood environmental effects on life and human health so that safety from hazardous effects associated with bacterial contamination and elevated concentration of toxic components may be ensured.

\section{EXPERIMENTAL}

\section{Sampling location}

Jacobabad and kashmor are two adjacent districts of Sind, Pakistan located at $28.2500^{\circ} \mathrm{N} \& 68.8333^{\circ} \mathrm{E}$ and $28.4333^{\circ} \mathrm{N} \& 69.5833^{\circ} \mathrm{E}$ respectively. A total of 175 water samples were collected from flood effected locations of both districts comprising 13 union councils and 47 villages as shown by highlighted areas on the map.

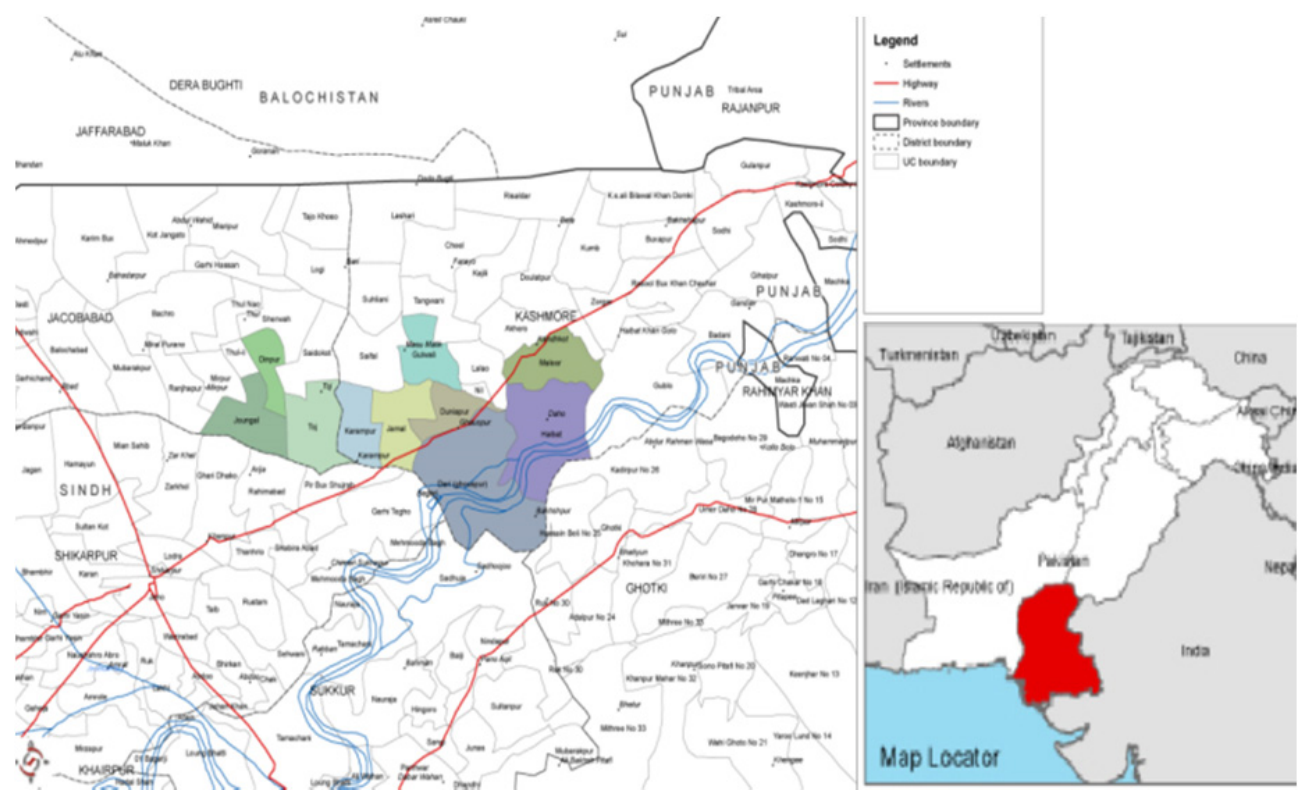

Fig. 2: Map of study area in district Jacobabad and Kashmor, Sindh 


\section{Water sample collection}

From each sampling site, three water samples were collected in clean poly propylene bottles $(600 \mathrm{ml})$ for physico-chemical, trace elements and aesthetic parameters evaluation. Water sample for microbiological analysis were collected in sterilized bottles $(250 \mathrm{ml})$, stored in ice box and shifted to water quality laboratory for immediate analysis.

\section{Reagent and instrumentation}

All chemicals and calibration reagent used for the study were of analytical grade and calibration of all instruments was done prior to use. Instruments employed for evaluation of chemical parameters includes Louibond PCH63739 Germany turbidity meter, Jenway $350 \mathrm{EU}$ pH meter,, HANNA HI 99300 Italy EC meter,Flame Photometer Italy, Optizen 2120 UV Plus Spectrophotometer, Mecasy Co. Ltd. Korea, HACH DR 2800 and Analytik Jena, AAS were used for analysis of chemical constituents and trace metals. $\mathrm{Ca}, \mathrm{Mg}$ and hardness were estimated by complexometric titration method using EDTA whereas $\mathrm{Cl}$ was analyzed by following argentometric titration methodology. TDS was calculated by addition of cations and anions and total coliform and faecal coliform organisms were tested by membrane filtration technique.

\section{Analytical investigation}

Field testing instruments were employed for testing of aesthetic and physical parameters like color, taste, turbidity and $\mathrm{pH}$ at sampling site and analysis data was recorded. Chemical analysis of other water quality parameters including electrical conductivity (EC), hardness, calcium $\left(\mathrm{Ca}^{+2}\right)$, sodium $\left(\mathrm{Na}^{+}\right)$, magnesium $\left(\mathrm{Mg}^{+2}\right)$, potassium $\left(\mathrm{K}^{+}\right)$, nitrate $\left(\mathrm{NO}_{3}^{-}\right)$, sulphate $\left(\mathrm{SO}_{4}^{-2}\right)$, fluoride $\left(\mathrm{F}^{-}\right)$, alkalinity, chloride $\left(\mathrm{Cl}^{-}\right)$, iron $(\mathrm{Fe})$, zinc $(\mathrm{Zn})$, arsenic (As) and TDS was carried out at PCRWR water quality laboratory applying APHA standard methods after proper calibration and standardization of instruments [35].

\section{Microbiological analysis}

Analysis of total coliform and faecal coliform organisms was done by following membrane filtration technique [36]. Water sample $(100 \mathrm{ml})$ was filtered through sterile filter paper $(0.45 \mu)$ using filtration assembly and placed on $\mathrm{m}$-Endo and $\mathrm{m}-\mathrm{FC}$ agar plates for analysis of total coliform and 
faecal coliform respectively. Typical coliform colonies have pink to dark red colour with metallic sheen and faecal coliform colonies have blue colour which was counted after incubation of $24 \mathrm{hrs}$ at $35^{\circ} \mathrm{C}$ and $45^{\circ} \mathrm{C}$ respectively.

\section{Health risk assessment}

Health hazard associated with ingestion of heavy metals through drinking water was studied by calculating chronic daily intake (CDI) and health risk index (HRI) for both adults and children by using equation $1 \& 2$ respectively $[37,38]$;

$$
\begin{aligned}
& C D I=\frac{M c \times L w}{W b} \\
& H R I=\frac{C D I}{R f D} \times 0.001
\end{aligned}
$$

where $\mathrm{Mc}(\mathrm{ppb})$ is the heavy metal concentration whereas Lw (L/day) denotes daily water intake that is assumed as $1 \mathrm{~L} /$ day for child and 2 $\mathrm{L} /$ day for adult and $\mathrm{Wb}(\mathrm{kg})$ is body weight of consumer that is considered as $32.7 \mathrm{~kg}$ and $72 \mathrm{~kg}$ for child and adult respectively [39]. RfD is the reference dose for oral toxicity which is $0.0003,0.7$ and $0.3 \mathrm{mg} \cdot \mathrm{kg}-1 \cdot \mathrm{day}-1$ for $\mathrm{As}, \mathrm{Fe}$ and $\mathrm{Zn}$ respectively, $\mathrm{HRI}$ is measured health risk index and 0.001 is the conversion factor used to downscale the reference dose (RfD) from $\mathrm{mg}$ to $\mu \mathrm{g}$. Water samples having $\mathrm{HRI}<1$ will be safe for consumption.

\section{Pollution index (Pi)}

Pollution index $(\mathrm{Pi})$ is an important indicator for estimating relative pollution due to individual water samples and is calculated by following equation;

$$
\text { Pollution index }(\mathrm{Pi})=\text { Concentration/Standard }
$$

Significant degree of pollution is indicated by water samples having $\mathrm{Pi}>1$ [40-41].

\section{ACKNOWLEDGEMENT}

The authors of this paper acknowledge the efforts of Pakistan Council for Research in Water Resources (PCRWR) staff for cooperation in water sample analysis. 
ASSESSMENT OF GROUNDWATER QUALITY AND ASSOCIATED HEALTH RISKS ...

\section{CONFLICT OF INTEREST}

The authors declare no conflict of interest.

\section{REFERENCES}

1. M. A. Malik, E. M. Azam, A. Saboor, "Water Quality Status of Upper KPK and Northern Areas of Pakistan", Water Resources Research Center, Peshawar, Ministry of Science and Technology, Peshawar, Report No.: 142, 2010.

2. W. H. Organization, "Trace Elements in Human Nutrition And Health", 1996.

3. M. Memon, M. S. Soomro, M. S. Akhtar, K. S. Memon, Environmental Monitoring and Assessment, 2011, 177, 39.

4. A. Adepoju-Bello, O. Alabi, The Nigerian Journal of Pharmacy, 2005, 37, 41.

5. A. Farooqi, H. Masuda, N. Firdous, Environmental Pollution, 2007, 145, 839.

6. J. Aziz, Eastern Mediterranean Health Journal, 2005, 11, 1087.

7. A. Azizullah, M. N. K. Khattak, P. Richter, D.P. Häder, Environment International, 2011, 37, 479.

8. T. U. Saeed, H. Attaullah, British Journal of Environment \& Climate Change, 2014, 4, 133.

9. S. A. Baig, X. Xu, M. N. Navedullah, Z. U. Khan, Journal of Applied Sciences in Environmental Sanitation, 2012, 7, 49.

10. S. Venkatramanan, S. Chung, T. Kim, M. Prasanna, S. Hamm, Water Quality, Exposure and Health, 2015, 7, 219.

11. M. M. Rahman, J. C. Ng, R. Naidu, Environmental Geochemistry and Health, 2009, 31, 189.

12. G. Akhter, Z. Ahmad, J. Iqbal, N. Shaheen, M. H. Shah, Journal of Chemical Society of Pakistan, 2010, 32, 306.

13. A. Alamgir, M. A. Khan, J. Schilling, S. S. Shaukat, S. Shahab, Environmental Monitoring and Assessment, 2016, 188, 1.

14. F. Perveen, U. Asghar, T. H. Usmani, Journal of Chemical Society of Pakistan, 2007, 29, 458.

15. T. Brock, K. Brock, "Basic Microbiology With Apllication $2^{\text {nd" }}$, Prentice Hall. Inc. New Jersey, 1978.

16. M. Sarfraz, N. Sultana, M. Jamil, R. Ashraf. Journal of Environmental Analytical Chemistry, 2016,3, 2.

17. R. F. Spalding, M. E. Exner, Journal of Environmental Quality, 1993, 22, 392.

18. C. Laluraj, G. Gopinath, Environmental Monitoring and Assessment, 2006, 117,45

19. F. T. Wakida, D. N. Lerner, Water Research, 2005, 39, 3.

20. W. H. Organization, 'World health statistics", World Health Organization, Geneva, 2010.

21. S. Butaciu, M Senila, C. Sarbu, M Ponta, C. Tanaselia, O. Cadar, M. Roman, E Radu, M. Sima, T Frentiu, Chemosphere, 2017, 172, 127. 
22. C. K. Jain, R. D. Singh, J. Environmental Management, 2012, 107, 1.

23. D. Mohan, C. U. Pittman Jr., Journal of Hazardous Materials, 2007, 142, 1.

24. S. Alam, Journal of Chemical Society of Pakistan, 2008, 30, 521.

25. S. T. Hakim, F. Afaque, S. Javed, S. U. Kazmi, S. G. Nadeem, Open Journal of Medical Microbiology, 2014, 4(2), 106.

26. Z. Jamshidzadeh and S. Mirbagheri, Desalination, 2011, $270,23$.

27. O. N. Nze, I. B. Ikechukwu, International Journal of Water Resources and Environmental Engineering, 2013, 5, 194.

28. S. A. Bablani, S. A. Soomro, "Evaluation of seawater intrusions in left bank sediments of coastal district Thatta, Sindh, Pakistan", 1st SWIM-SWICA Joint Saltwater Intrusion Conference. 2006, 24-29.

29. N. J. Ashbolt, Toxicology, 2004, 198, 229.

30. R. W. Tuthill, E. J. Calabrese, Archives of Environmental Health: An International Journal, 1979, 34, 197.

31. D. Tiwari, Indian Journal of Environmental Health, 2001, 43, 176.

32. A. A. Khan, H. Whelton, D. O'Mullane, International Dental Journal, 2002, 52, 291.

33. I. A. Al-Saleh, Science of Total Environment, 1996, 181, 215.

34. D. Van Halem, S. Olivero, W. de Vet, J. Verberk, G. Amy, J. van Dijk, Water Research, 2010, 44, 5761

35. APHA, "Standard methods for the examination of water and wastewater". 2005, 21, 258.

36. P. dll Version, "Method 1603: Escherichia coli (E. coli) in Water by Membrane Filtration using Modified membrane-Thermotolerant Escherichia coli Agar (Modified mTEC)", 2003.

37. M. Shah, J. Ara, S. Muhammad, S. Khan, S. Tariq, Journal of Geochemical Exploration, 2012,118, 60.

38. S. Muhammad, M. T. Shah, S. Khan, Food and Chemical Toxicology, 2010, 48, 2855.

39. F. A. Jan, M. Ishaq, S. Khan, I. Ihsanullah, I. Ahmad, M. Shakirullah, Journal of Hazardous Materials, 2010, 179, 612.

40. O. Akpoveta, B. Okoh, S. Osakwe, Current Research in Chemistry, 2011, 3, 62.

41. U. Umeobika, V. Ajiwe, M. Iloamaeke, C. Alisa, International Journal of Science Innovations and Discoveries, 2013, 3, 56. 